\title{
Pasienters livsstil er vanskelig å endre
}

\section{Én konsultasjon hos leger eller sykepleiere som er kurset i motiverende intervjuteknikk, fører ikke til endret livsstil hos pasientene.}

Røyking, høyt alkoholforbruk, mangel på mosjon og usunt kosthold er de viktigste påvirkbare årsakene til sykelighet og død i den vestlige verden. En britisk forskergruppe har undersøkt om kurs i motiverende intervjuteknikk for ansatte i primærhelsetjenesten kan påvirke pasientenes livsførsel på disse fire områdene (1). Leger og sykepleiere ved

13 allmennlegekontorer ble kurset gjennom seminarer, e-læring og simulerte konsultasjoner. 831 pasienter som ut fra visse kriterier hadde en usunn livsstil, fikk en konsultasjon hos en kurset lege/sykepleier. 14 allmennlegekontorer med 996 tilsvarende pasienter fungerte som kontrollgruppe. Her ble det gjennomført vanlige konsultasjoner.
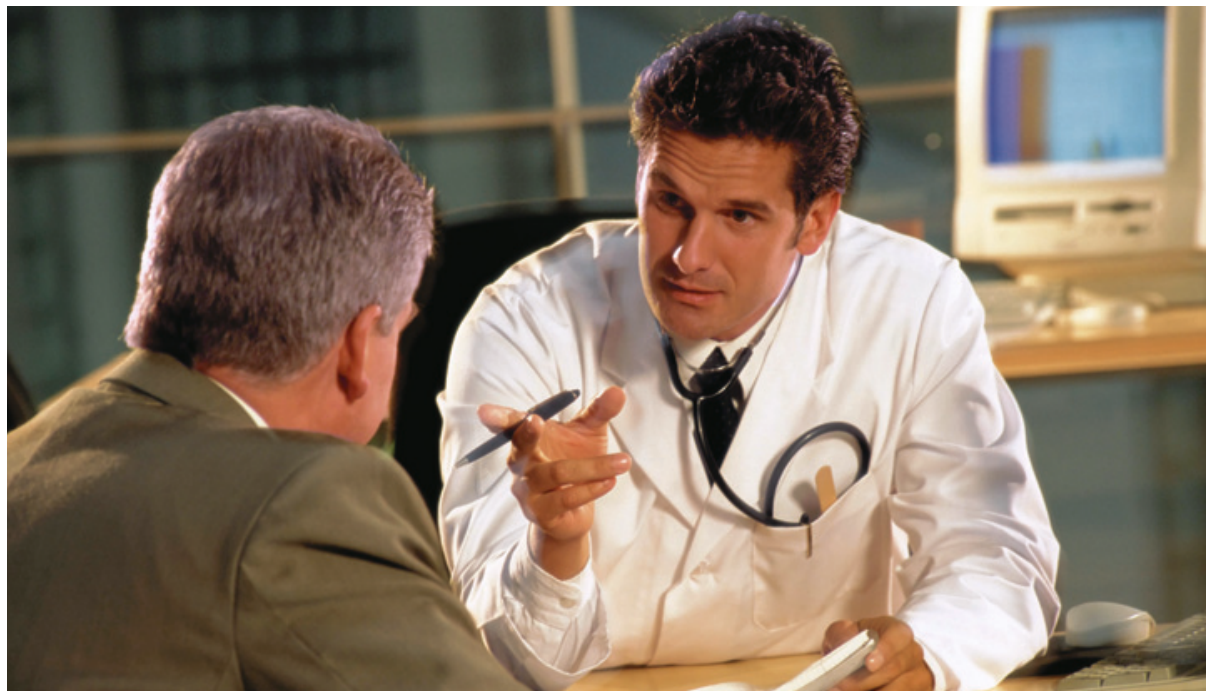

Illustrasjonsfoto Image Source/NTB scanpix
Etter tre måneder rapporterte pasientene i intervensjonsgruppen om uendret livsstil, men de hadde et større ønske om livsstilsendring og hadde gjort flere forsøk på å endre livsstil enn pasientene i kontrollgruppen.

- Denne studien bekrefter at én enkelt konsultasjon med motiverende intervju ikke er tilstrekkelig for å oppnå atferdsendring hos pasientene. Studier som viser effekt av motiverende intervjuer i allmennpraksis inneholder alle en mer omfattende intervensjon, med en viss grad av oppfølging av pasienten over tid, sier professor Arnstein Finset ved Avdeling for medisinsk atferdsvitenskap, Universitetet i Oslo.

- I en nederlandsk oversiktsartikkel publisert i Patient Education and Counseling i 2012, rapporterte man i 8 av 14 studier atferdsendringer som følge av motiverende intervjuer i primærhelsetjenesten. Dette tyder på at motiverende intervju kan være en god metode i allmennpraksis, men at oppfølging utover én enkelt konsultasjon er nødvendig, sier Finset.

\section{Sigurd Høye}

sigurd.hoye@legeforeningen.no

Tidsskriftet

\section{Litteratur}

1. Butler CC, Simpson SA, Hood K et al. Training practitioners to deliver opportunistic multiple behaviour change counselling in primary care: a cluster randomised trial. BMJ 2013; 346: f1191.

\section{Antibiotika virker ikke gjennom reaktive oksygenforbindelser}

\section{Hypotesen om at antibiotika fører \\ til danningen av reaktive oksygen- forbindelser med baktericid effekt, får ikke støtte i ny studie.}

Studier det siste tiåret har reist hypotesen om at klassiske antibiotika dreper bakterier ved en felles, indirekte mekanisme, i tillegg til de kjente virkningsmekanismene. Ifølge denne hypotesen stimulerer antibiotika til danningen av reaktive oksygenforbindelser med baktericid effekt. To amerikanske forskergrupper har testet om dette er tilfellet $(1,2)$.

I ulike eksperimenter med kinoloner, betalaktamer og aminoglykosider var den bakteriedrepende effekten den samme under både aerobe og anaerobe forhold. Det ble ikke påvist noen økning i produksjonen av hydrogenperoksid i celler eksponert for antibiotika. Det var heller ingen sammenheng mellom produksjonen av reaktive oksygenforbindelser og oksidativ DNA-skade eller bakterieoverlevelse.

- Til tross for omfattende forskning og klinisk bruk gjennom mange tiår har vi fortsatt mangelfull forståelse av hvordan våre viktigste antibiotika virker på bakterier, sier professor Gunnar Skov Simonsen, leder for Norsk overvåkingssystem for antibiotikaresistens hos mikrober ved Universitetssykehuset Nord-Norge.

- Med økende forekomst av antibiotikaresistens er slik kunnskap viktig for optimal antibiotikabruk og for utvikling av nye mid- ler. Disse studiene tilbakeviser hypotesen om danning av reaktive oksygenforbindelser som en felles virkningsmekanisme ved bakeriedrapet, og det er uavklart om det virkelig finnes en slik mekanisme. Kunnskapen om virkningsmekanismene knyttet til metabolisme av cellevegg, proteiner og nukleinsyrer gjelder fortsatt, sier Simonsen.

\section{Trine B. Haugen \\ trine.b.haugen@hioa.no \\ Tidsskriftet}

\section{Litteratur}

1. Liu Y, Imlay JA. Cell death from antibiotics without the involvement of reactive oxygen species. Science 2013: 339: 1210-3.

2. Keren I, Wu Y, Inocencio J et al. Killing by bactericidal antibiotics does not depend on reactive oxygen species. Science 2013; 339: 1213-6. 